\title{
Optimization of Legal Education for Drugs Abuse Prevention in Tegalrejo District Yogyakarta
}

\author{
Muhammad Ramadhan ${ }^{1 *}$, Dwi Oktafia Ariyanti ${ }^{2}$, Ridwan Arifin $^{3}$ \\ 1 Faculty of Law, Universitas Janabadra, Yogyakara, Indonesia \\ ${ }^{2}$ Faculty of Law, Universitas Janabadra, Yogyakara, Indonesia \\ 3 Faculty of Law, Universitas Negeri Semarang, Indonesia \\ *Corresponding Author: M. Ramadhan, email: muhammad_ramadhan@janabadra.ac.id
}

\begin{abstract}
Drug abuse as an extraordinary crime is carried out by involving many countries and a very large network, including Indonesia and especially in the province of D.I. Yogyakarta, known as a student city. However, the predicate city of students cannot make the province of D.I. Yogyakarta free from the dangers of drugs, instead it is ranked as the first province in Indonesia with the most users. Thus the need for education and understanding provided to the community, especially in the Tegalrejo sub-district region, is expected to reduce the number of drug users. The educational activities carried out received enthusiasm from the residents of Tegalrejo, which was attended by many residents from various backgrounds, starting from community leaders, village officials and attended by local youth or youth. From legal education activities to the dangers of drugs, participants who participate in these activities can understand all kinds of forms and types of drugs, apart from that, they also get knowledge of the effects of the dangers of drugs and can find out the characteristics of users to be more aware of in social relations with others. The advice given is to collect suspicious migrant data and strengthen positive activities from village officials and youth organizations so that Tegalrejo subdistrict is free from drug threats.
\end{abstract}

Keywords: Drugs Abuse, Narcotics, Crime, Legal Education

\section{How to cite:}

Ramadhan, M., Ariyanti, D.O., \& Arifin, R. (2020). Optimization of Legal Education for Drugs Abuse Prevention in Tegalrejo District Yogyakarta. Indonesian Journal of Advocacy and Legal Services, 1(2), 193-204. DOI: 10.15294/ijals.v1i2.33808 


\section{A. Introduction}

Indonesia is currently a country that has become the target of drug dealers. Various types of drugs are often smuggled by foreign citizens to enter Indonesia and make Indonesia a haven for dealers because of the high number of drug users in the country of Indonesia. Drug trafficking in Indonesia continues to increase every year, based on data obtained from the National Narcotics Agency (BNN) stating that there is an increase in drug abuse, especially among adolescents, where an increase of 24 to 28 percent of adolescent drug addicts in 2017-2018, which a few years ago was only 20 percent. ${ }^{1}$

Narcotics itself is an extension of Narcotics, Psychotropics and Additives, or another term known as drugs. Narcotics itself is a substance or drug that comes from plants or not plants, both synthetic and semisynthetic, which can cause a decrease or change of consciousness, loss of taste, reduce to eliminate pain, and can cause dependence. ${ }^{2}$ As well as psychotropic substances or drugs, both natural and synthetic non-narcotics, which have psychoactive properties through selective influences on the central nervous system that cause changes in mental activity and behaviour. ${ }^{3}$ Basically narcotics, psychotropic substances or additives are hard drugs used in the medical world intended for treatment, therefore their use must be with the right prescription and monitored by medical personnel, because the effects of narcotics are very dangerous.

Drug abuse in the Yogjakarta province, especially among adolescents, ranks first as a drug user in Indonesia. This makes it very sad that Jogjakarta is known as a student city, a city filled with educated teenagers and even more teenagers are the next generation and the future of the Indonesian nation. Distribution of drugs itself in several regions in the

1 BNN PUSLIDATIN, Penggunaan Narkotika di Kalangan Remaja Meningkat, 12 August 2019, https://bnn.go.id/penggunaan-narkotika-kalangan-remaja-meningkat/

Law Number 35 of 2009 concerning Narcotics.

3 Law Number 5 of 1997 concerning Psychotropics. Psychotropic drugs are not designed to work instantly. For some, the medications can begin working in several weeks while others may need to try several different medications before finding the right one. For more comprehensive insight, see Kristalyn Salters-Pedneault, Understanding Psychotropic Drugs, 25 September 2019, https://www.verywellmind.com/psychotropicdrugs-425321. Some drugs in addition to having a positive effect in the medical world, but also has a negative impact, erama associated with emotional and psychological changes in a person. So that in many countries, including Indonesia, the misuse of drugs becomes one of the criminal offenses that is threatened with crime, see T. S. Sathyanarayana Rao \& Chittaranjan Andrade, Classification of psychotropic drugs: Problems, solutions, and more problems, Indian J Psychiatry, 2016 Apr-Jun; 58(2), pp, 111-113. doi: 10.4103/0019-5545.183771 
Province of Yogjakarta by BNNP get a division of drug-prone areas including drug-prone level I and level II drug prone. In the distribution of drug-prone areas, Tegalrejo sub-district is an area that is ranked secondlevel drug prone. Therefore, residents who live in Tegalrejo sub-district need education on the dangers of drugs as well as teenagers as the next generation of the nation must be saved from the dangers of drugs. The purpose of this community service activity is to provide education and knowledge about the effects caused by drugs.

\section{B. Method}

The method used in the implementation of these community service activities is by providing education to the community of Tegalrejo subdistrict to the dangers posed by drug abuse especially among adolescents. The education provided is in the form of material exposure regarding types, modus operandi, the impact of misuse, the characteristics of drug users and the sanctions provided if they violate the provisions of the laws and regulations.

Apart from providing education about the dangers of drugs, there is also a discussion or question and answer session between Tegalrejo residents and presenters so that citizens can better understand the dangers of drugs. In this session, every citizen is given the freedom to ask questions about the dangers of drugs and solutions to be done if there are citizens who become drug addicts.

\section{Result and Discussion}

\section{Legal Education Concept for Preventing Crimes}

Legal education, as used here, refers to experiences and training which help different kinds of people to understand and use law in society. Our primary focus is upon university institutions which provide intensive, structured education in law, but we think a report on legal education addressed to development should adopt a much broader perspective of needs for legal education. A citizen, to be effective in enjoyment of his civic capacities, needs a basic knowledge of at least some aspects of law. Officials and others who perform important law roles-e.g., as policemen, businessmen or politicians-need an understanding of parts of the law and its underlying policies and values. The proliferation and specialization of various new activities may call for particularized kinds of legal education. ${ }^{4}$

4 Jorge Avendafio, et al, Legal Education in a Changing: World Report of the Committee on Legal Education in the Developing Countries, New York, International Legal Center, 
Furthermore, Avendafio et.al also emphasized that historically, in many different societies, law has been one of the pre-eminent fields of higher learning and a route to positions of importance. The tendency of lawtrained persons to gravitate to significant centers of decision-making exists in many different societies today. It is, of course, not inevitable, but where it exists, it is a fact to be taken into account in evaluating the importance of legal education. Therefore, Legal Education recognized as an Avenue to the World of Affairs. ${ }^{5}$

It is also highlighted that, typically, the discipline of law is regarded as part of the humanities. This is so because: ( $a$ ) law covers so many human activities and relationships; but (b) it also deals with much of the same phenomena as the social sciences, and is increasingly informed by them; and (c) it is intellectually demanding-requiring abilities to draw from a variety of sources in analyzing problems, evidence and arguments to make careful distinctions and to handle abstract concepts; and $(d)$ it is directly related to the world of concrete practical problems; and $(e)$ it is concerned, as perhaps no other subject is concerned, with the practical operation of processes and procedures; and $(f)$ it has a rich heritage of literature, philosophy and historical experience. ${ }^{6}$

Popkewitz, Olsson, and Petersson concerning to legal education on preventing crimes, emphasized that the 'learning society' expresses principles of a universal humanity and a promise of progress that seem to transcend the nation. They highlighted how the society is governed in the name of a cosmopolitan ideal that despite its universal pretensions embodies particular inclusions and exclusions. These occur through inscribing distinctions and differentiations between the characteristics of those who embody a cosmopolitan reason that brings social progress and personal fulfilment and those who do not embody the cosmopolitan principles of civility and normalcy. Mapping the circulation of the notion of the 'learning society' in arenas of Swedish health and criminal justice, and Swedish and US school reforms is to examine the mode of life of the citizen of this society, the learner, as an 'unfinished cosmopolitanism' and also directs attention to its 'other(s)' - those that are outside. ${ }^{7}$

1975, p. 26.; Dwi Oktafia Ariyanti \& Muhammad Ramadhan, Legal Education against the Impact of Social Media in the Era of Information Disclosure for Pringgokusuman Residents in Yogyakarta, Indonesian Journal of Advocacy and Legal Services, Vol. 1 No. 1, pp. 129-134. https://doi.org/10.15294/ijals.v1i1.33768

5 Jorge Avendafio, et al, Ibid., p. 38.

6 Ibid.

7 Thomas S. Popkewitz, Ulf Olsson, and Kenneth Petersson. "The learning society, the unfinished cosmopolitan, and governing education, public health and crime prevention 
Moreover, in the context of crimes prevention, Reid highlighted the concept of crimes it self, that according to him, crime formulates the basis for a study of criminal behaviour. In the further context, he said crime as deviant behaviour. ${ }^{8}$ Therefore, some crimes are needed a special treatment, especially if the crimes involved the juveniles or insignificant crimes, such as penal mediation. ${ }^{9}$

\section{Implementation of Legal Education to Prevent Drugs Abuse}

Innovation, resistance and conformity have been the hall marks of legal education in global South. One of the recent paradigms has given a clarion call to alter legal education into justice education ${ }^{10}$, including in Indonesia. Drugs abuse has become a serious problem, especially nowadays. Previous research showed that initial 430 potential studies identified, nine quantitative studies met the inclusion criteria. Studies evaluated compulsory treatment options including drug detention facilities, short (i.e., 21-day) and long-term (i.e., 6 months) inpatient treatment, communitybased treatment, group-based outpatient treatment, and prison-based treatment. Three studies (33\%) reported no significant impacts of

at the beginning of the twenty-first century." Contesting Governing Ideologies, Routledge, London, 2017, pp. 68-87.

8 Sue Titus Reid, Crime and criminology. Wolters Kluwer Law \& Business, London, 2015, pp. 56-57.

9 Sri Hartanto, Indah Sri Utari, Ridwan Arifin, Implementation of Penal Mediation in The Perspective of Progressive Law (Study at The Semarang City Police Department), IJCLS (Indonesian Journal of Criminal Law Studies), Vol. 4 No. 2, 2019, pp. 161-188. DOI: https://doi.org/10.15294/ijcls.v4i2.21494; Ridwan Arifin, How to advocate for people who have problems with the law? A Book Review Communication in Legal Advocacy, Richard Ricke \& Randall K. Stutman, South Carolina University Press, Indonesian Journal of Advocacy and Legal Services, Vol. 1 No. 1, 2019, pp. 153-160. https://doi.org/10.15294/ijals.v1i1.33807. Concerning o punishment for juveniles, It is emphasized that enalty imposed on children in their enforcement must see various considerations in binding human rights and the role of the community itself within the scope of society for that social system is very instrumental in the guidance of children who are deemed to have violated the rules in force at that time and in the rules that were set from the beginning with the initial thus the community plays an active role compared to the established criminal penalties such as prison and confinement. But basically the sentence has an educational nature to it in the thinking of a figure taken from M.J. Langeveld in his book Beknopte Theorishe Paedagogiek argues that punishment is an act in which we consciously even intentionally impose misery on someone both physically and spiritually, having various weaknesses and impacts both for children who are given sanctions or punishment and for the community, see Ria Juliana \& Ridwan Arifin, Anak dan Kejahatan (Faktor Penyebab dan Perlindungan Hukum), Jurnal Selat, Vol. 6 No. 2, 2019, pp. 225-234. https://ojs.umrah.ac.id/index.php/selat/article/view/1019.

10 Shashikala Gurpur \& Rupal Rautdesai, Revisiting Legal Education for Human Development: Best Practices in South Asia, Procedia - Social and Behavioral Sciences $\begin{array}{lllll}\text { Volume } & 157,27 & \text { November } & 2014, & \text { pp. }\end{array}$ https://doi.org/10.1016/j.sbspro.2014.11.028 
compulsory treatment compared with control interventions. Two studies (22\%) found equivocal results but did not compare against a control condition. Two studies (22\%) observed negative impacts of compulsory treatment on criminal recidivism. Two studies (22\%) observed positive impacts of compulsory inpatient treatment on criminal recidivism and drug use. ${ }^{11}$

Another researches, in the same context, showed that student knowledge and views regarding government versus private rehabilitation centers, as well as their exposure to, and views about, school-based drugprevention education is very variatives. It is also emphasized that drug users, in other words, were portrayed as from lower socioeconomic strata, often resorting to crime to fund their habit. Recent reports, however, suggest that drug users come from many different backgrounds, with white collar workers, civil servants, college students, and adolescents all represented in significant numbers. ${ }^{12}$

Furthermore, to prevent drugs abuse, education as well as socialization recognized as the most effective ways. It is as highlighted by Maharg, that in the legal education is need to be cautious about the place of theory in discussion of legal education for two reasons. Firstly, in education (and particularly educational psychology) there are strong positivist traditions of empirical theory and research that hold to what might loosely be termed a 'black box' view of human learning. The tradition is most closely associated with laboratory research paradigms, and adheres to a pre-test, test and post-test model of research. Second, and related to the first point, it is often the case in education that an openness to alternatives in theory is essential. Legal education rarely tolerates theoretical absolutes. ${ }^{13}$

In the same context, it is also emphasized that implementation of supervisory duty on illicit drug trafficking is needed joint effort between law enforcement apparatus and all societyelememt. The large amount of drugs

11 D.Werb, A. Kamarulzaman, M. C. Meacham, C. Rafful, B. Fischer, S. A. Strathdee, \& E. Wood, The Effectiveness of Compulsory Drug Treatment: A Systematic Review. International Journal of Drug Policy, Volume 28, 2016, pp.1-9. https://doi.org/10.1016/j.drugpo.2015.12.005

12 Qiu Ting Chie, Cai Lian Tam, Gregory Bonn, Chee Piau Wong, Hoang Minh Dang and Rozainee Khairuddin, Drug abuse, relapse, and prevention education in Malaysia: perspective of university students through a mixed methods approach, Frontiers in Psychiatry, Vol. 6(65), 2015, pp. 1-13. https://doi.org/10.3389/fpsyt.2015.00065.

13 Paul Maharg, Transforming Legal Education Learning and Teaching the Law in the Early Twenty-first Century, Routledge, London, 2016, pp. 17-18; Restiana Pasaribu, Fight Narcotics with Community Strengthening: Crime Control Management by Community Policing, JILS (Journal of Indonesian Legal Studies), Vol. 3 No. 2, 2018, pp. 237-252. https://doi.org/10.15294/jils.v3i02.27533 
abuse needs to get more attention, especially in the case of drug abuse prevention. The number of drugs abuse must be minimized so that the problem of drugs abuse is not widespread. Efforts to overcome the abuse of drug trafficking is a shared responsibility between family, community and government. ${ }^{14}$

Moreover, the problem of drugs abuse as well as illegal drugs trafficking beside need the integrated cooperation between stakeholders, also need to formulate a good laws and regulations to responds the problems, ${ }^{15}$ as well o prevent the drugs abuse through education and community empowernment

In Yogyakarta, legal education to prevent drugs abuse, held in the district of Tegalrejo D.I. Yogyakarta runs smoothly, while the participants who attend the education consist of community leaders, village residents and youth groups. Throughout the activity the participants were enthusiastic and this was indicated by the number of participants who attended more than 50 people and the tranquility throughout the activity.

This activity is carried out in 2 stages, in the first stage educational activities on the substance of the drug are carried out with 2 (two) speakers conducted in a language that is straightforward and easy to understand, with the first speaker giving material to the drug itself, namely the origin of the drug, the utilization drugs that are appropriate for their use, recognize the types of drugs in circulation, their effects, the modus operandi of dealers and the characteristics of drug users. ${ }^{16}$

Here the residents are explained about the origin of opium which was first used by the Sumerians as a plant of happiness which was further used in the past as a medicine for pain relief during medical operations, with this information residents can know that basically the use of drugs is permitted as long as it is carried out for medical world in terms of treatment carried out by prescription and proper supervision. Apart from that the residents were also informed of the types of drugs and their inheritance, including Marijuana, Methamphetamine, Opium, Heroin, Cocaine and Ecstasy, the introduction of these types of citizens is expected to be able to understand

14 Restiana Pasaribu, Fight Narcotics with Community Strengthening: Crime Control Management by Community Policing, JILS (Journal of Indonesian Legal Studies), Vol. 3 No. 2, 2018, p. 239.

15 Indah Sri Utari \& Ridwan Arifin, Law Enforcement and Legal Reform in Indonesia and Global Context: How the Law Responds to Community Development?, Journal of Law and Legal Reform, Vol. 1 No. 1, 2019, pp. 1-4. https://doi.org/10.15294/jllr.v1i1.35772

16 Romli Atmasasmita, Tindak Pidana Narkotika Transnasional dalam Sistem Hukum Pidana Indonesia, Citra Aditya Bakti, Bandung, 2013, pp. 64-66. 
the shape of these prohibited objects in order to avoid and report to the authorities if they know the existence drugs. ${ }^{17}$

The modus operandi presented by the speaker is with the aim of citizens being able to anticipate the dealers who are around, especially the migrants in Tegalrejo, as many of the modus operandi by the dealer include being distorted in a workshop or in books and other objects which are then circulated. Besides that the speaker also explained the characteristics of drug users in the hope that residents could know if one of the Tegalrejo residents were users so that further treatment could be done in the hope that the drug users could be rehabilitated. ${ }^{18}$

The second speaker explained about the sanctions in effect from the provisions of the law, as for acts that can be ensnared by law if carrying out activities related to drugs without proper supervision, such as the threat of punishment for those who own, store, plant, produce, sell and sell buying as well as drug abuse. By providing information on legal sanctions, it is expected that Tegalrejo residents will supervise each other, especially teenagers, so that they do not engage in drug-related activities.

In the final stage of the drug dangers, a question and answer session was held between residents and presenters, here seemed enthusiastic about the public asking questions about the presentations that had been delivered by the speakers. Activities that last for approximately 3 hours can run smoothly without any obstacles or obstacles. At the end of the activity conclusions can be drawn to residents of Tegalrejo including more supervision of adolescents, data collection on migrants who are in Tegalrejo and holding positive activities to avoid the dangers of drugs.

\section{Conclusion}

The knowledge of Tegalrejo residents is increasingly on the dangers of drugs. Education provided is a step to convey information about the dangers and legal sanctions for drug abuse. The awareness of residents to keep Tegalrejo free from drugs is higher with increased supervision and siskamling activities around the Tegalrejo area.

17 Hari Sasangka, Narkotika dan Psikotropika dalam Hukum Pidana, Mandar Maju, Bandung, 2011, pp. 25-29; Kusno Adi, Kebijakan Kriminal dalam Penanggulangan Tindak Pidana Narkotika oleh Anak, UMM Press, Malang, 2014, pp. 54-57.

18 Supreme Court Circular No. 3 of 2011 concerning the Placement of Victims of Drug Abuse in the Institute for Medical Rehabilitation and Social Rehabilitation 


\section{E. Acknowledgments}

These remarks were conveyed to the University of Janabadra, Tegalrejo Sub-District Head, village head, community leaders, Karang Taruna Tegalrejo Chairperson and all the organizers of the legal hazard education activities.

\section{F. Declaration of Conflicting Interests}

The authors state that there is no potential conflict of interest in the research, authorship, and / or publication / publication of this article.

\section{G. Funding}

Program of the community services and research funded by Research Program Grant, Research and Community Service Institute, Universitas Janabadra Yogyakara, Indonesia, 2019.

\section{H. References}

Adi, K. (2014). Kebijakan Kriminal dalam Penanggulangan Tindak Pidana Narkotika oleh Anak. Malang: UMM Press.

Arifin, R. (2019). How to advocate for people who have problems with the law? A Book Review Communication in Legal Advocacy, Richard Ricke \& Randall K. Stutman, South Carolina University Press. Indonesian Journal of Advocacy and Legal Services, 1(1), 153-160. https://doi.org/10.15294/ijals.v1i1.33807.

Ariyanti, D.O., \& Ramadhan, M. (2019). Legal Education against the Impact of Social Media in the Era of Information Disclosure for Pringgokusuman Residents in Yogyakarta, Indonesian Journal of Advocacy and Legal Services, 1(1), 129-134. https://doi.org/10.15294/ijals.v1i1.33768

Atmasasmita, R. (2013). Tindak Pidana Narkotika Transnasional dalam Sistem Hukum Pidana Indonesia. Bandung: Citra Aditya Bakti.

Avendafio, J. et al, (1975). Legal Education in a Changing: World Report of the Committee on Legal Education in the Developing Countries. New York: International Legal Center.

BNN PUSLIDATIN. (2019). Penggunaan Narkotika di Kalangan Remaja Meningkat, 12 August, https://bnn.go.id/penggunaan-narkotikakalangan-remaja-meningkat/ 
Chie, Q. T., Tam, C.L., Bonn, G., Wong, C.P., Dang, H.M., \& Khairuddin, R. (2015). Drug abuse, relapse, and prevention education in Malaysia: perspective of university students through a mixed methods approach, Frontiers in Psychiatry, 6(65), 1-13. https://doi.org/10.3389/fpsyt.2015.00065.

Gurpur, S., \& Rautdesai, R. (2014). Revisiting Legal Education for Human Development: Best Practices in South Asia,. Procedia - Social and Behavioral Sciences, 157(November), 254-265, https://doi.org/10.1016/j.sbspro.2014.11.028

Hartanto, S., Utari, I.S., \& Arifin, R. (2019). Implementation of Penal Mediation in The Perspective of Progressive Law (Study at The Semarang City Police Department), IJCLS (Indonesian Journal of Criminal Law Studies), $4(2), \quad$ 161-188. DOI: https://doi.org/10.15294/ijcls.v4i2.21494

Juliana, R., \& Arifin, R. (2019). Anak dan Kejahatan (Faktor Penyebab dan Perlindungan Hukum), Jurnal Selat, 6(2), 2019, 225-234. https://ojs.umrah.ac.id/index.php/selat/article/view/1019.

Law Number 35 of 2009 concerning Narcotics. Republic of Indonesia State Gazette of 2009 Number 143, Supplement to Republic of Indonesia State Gazette of 2009 Number 5062. [Undang Undang No. 35 Tahun 2009 Tentang Narkotika. Lembaran Negara Republik Indonesia Tahun 2009 Nomor 143, Tambahan Lembaran Negara Republik Indonesia Tahun 2009 Nomor 5062]. Retrieved from https://www.hukumonline.com/pusatdata/detail/lt4af3b7f6cf607/unda ngundang-nomor-35-tahun-2009\#

Law Number 5 of 1997 concerning Psychotropics. Republic of Indonesia State Gazette of 1997 Number 10, Supplement to the Republic of Indonesia State Gazette Number 3671 [Undang-Undang Nomor 5 Tahun 1997 Tentang Psikotropika. Lembaran Negara Republik Indonesia Tahun 1997 Nomor 10, Tambahan Lembaran Negara Republik Indonesia Nomor 3671]. Retrieved from http://epharm.depkes.go.id/front/pdf/UU51997.pdf

Maharg, P. (2016). Transforming Legal Education Learning and Teaching the Law in the Early Twenty-first Century. London: Routledge.

Pasaribu, R. (2018). Fight Narcotics with Community Strengthening: Crime Control Management by Community Policing, JILS (Journal of Indonesian Legal Studies), 3(2), 237-252. https://doi.org/10.15294/jils.v3i02.27533

Popkewitz, T.S., Olsson, U., \& Petersson, K. (2017). "The learning society, the unfinished cosmopolitan, and governing education, public health and crime prevention at the beginning of the twenty-first century." Contesting Governing Ideologies. London: Routledge.

Rao, T.S.S., \& Andrade, C. (2016). Classification of psychotropic drugs: Problems, solutions, and more problems. Indian J Psychiatry, 58(2), 111-113. doi: 10.4103/0019-5545.183771 
Reid, S.T. (2015). Crime and Criminology. London: Wolters Kluwer Law \& Business.

Salters-Pedneault, K. (2019). Understanding Psychotropic Drugs, 25 September, https://www.verywellmind.com/psychotropic-drugs425321.

Sasangka, H. (2011). Narkotika dan Psikotropika dalam Hukum Pidana. Bandung: Mandar Maju.

Supreme Court Circular No. 3 of 2011 concerning the Placement of Victims of Drug Abuse in the Institute for Medical Rehabilitation and Social Rehabilitation. [Surat Edaran Mahkamah Agung No. 3 Tahun 2011 Tentang Penempatan Korban Penyalahgunaan Narkoba di Dalam Lembaga Rehabilitasi Medis dan Rehabilitasi Sosial]. Retrieved from https://bawas.mahkamahagung.go.id/bawas_doc/doc/sema_03_2011.p df

Utari, I.S., \& Arifin, R. (2019). Law Enforcement and Legal Reform in Indonesia and Global Context: How the Law Responds to Community Development? Journal of Law and Legal Reform,1(1), 1-4. https://doi.org/10.15294/jllr.v1i1.35772

Werb, D., Kamarulzaman, A., Meacham, M. C., Rafful, C., Fischer, B., Strathdee, S. A., \& Wood, E. (2016). The Effectiveness of Compulsory Drug Treatment: A Systematic Review. International Journal of Drug Policy, 28, pp.1-9. https://doi.org/10.1016/j.drugpo.2015.12.005 


\title{
QUOTE
}

\section{Strength does not come from physical capacity. It comes from an indomitable will.}

\author{
Mahatma Gandhi
}

Copyrights (C) 2020 by Auhtor(s). This work is licensed under a Creative Commons Attribution-NonCommercial-ShareAlike 4.0 International License. All writings published in this journal are personal views of the authors and do not represent the views of this journal and the author's affiliated institutions. 